\title{
METODE PERCOBAAN SEDERHANA \\ DALAM PEMANFAATAN BARANG BEKAS \\ MENJADI KARYA SENI RUPA MAHASISWA FKIP PGSD UNIVERSITAS MUHAMMADIYAH PALANGKARAYA
}

\author{
OLEH : Ichyatul Afrom \\ Dosen PGSD FKIP Universitas Palangka Raya
}

\begin{abstract}
ABSTRAK
Pembelajaran yang berkualitas sangat tergantung dari motivasi pelajar dan kreatifitas pengajar. Pembelajar yang memiliki motivasi tinggi ditunjang dengan pengajar yang mampu memfasilitasi motivasi tersebut akan membawa pada keberhasilan pencapaian target belajar. Target belajar dapat diukur melalui perubahan sikap dan kemampuan siswa melalui proses belajar. Desain pembelajaran yang baik, ditunjang fasilitas yang memandai, ditambah dengan kreatifitas guru akan membuat peserta didik lebih mudah mencapai target belajar.

Luaran yang diharapkan adalah data hasil penelitian ini dapat digunakan untuk acuan pembelajaran kepada mahasiswa yang memprogramkan mata kulih Pendidikan Seni agar dapat benar-benar menguasai seni khususnya seni rupa dan dapat menerapkannya pada saat mereka sudah menjadi guru. Selain itu, untuk memacu motivasi dosesn-dosen yang mengampu mata kuliah praktik dalam memanfaatkan metode pembelajaran yang berhubungan dengan materi yang diajarkan.
\end{abstract}

\section{Kata Kunci : Metode Percobaan Sederhana, Barang Bekas}

\section{PENDAHULUAN}

Pembelajaran adalah proses interaksi peserta didik dengan pendidik dan sumber belajar pada suatu lingkungan belajar. Pembelajaran merupakan bantuan yang diberikan pendidik agar dapat terjadi proses perolehan ilmu dan pengetahuan, penguasaan kemahiran dan tabiat, serta pembentukan sikap dan kepercayaan pada peserta didik. Dengan kata lain, pembelajaran adalah proses untuk membantu peserta didik agar dapat belajar dengan baik.

Kreativitas merupakan ungkapan unik dari keseluruhan kepribadian sebagai hasil interaksi individu dengan lingkungannya, dan yang tercermin dalam pikiran, perasaan, sikap atau perilakunya.

Kreativitas dimulai dengan kemampuan individu untuk menciptakan sesuatu yang baru. Biasanya seorang individu yang kreatif memiliki sifat yang mandiri. Ia tidak merasa terikat pada nilai-nilai dan norma-norma umum yang berlaku dalam bidang keahliannya. Ia memiliki sistem nilai dan sistem apresiasi hidup sendiri yang mungkin tidak sama dengan nilainilai yang dianut oleh masyarakat ramai. Pendidikan seni merupakan saran untuk pengembangan kreativitas. Pelaksanaan pendidikan seni dapat dilakukan melalui kegiatan permainan. Tujuan pendidikan seni bukan untuk membina anak-anak menjadi seniman, melainkan untuk mendidik anak menjadi kreatif. Seni merupakan aktivitas permainan. Melalui permainan, kita dapat mendidik anak dan membina kreativitasnya sedini mungkin. Dengan demikian dapat dikatakan bahwa seni dapat digunakan sebagai alat pendidikan. Melalui permainan dalam pendidikan seni anak memiliki keleluasaan untuk mengembangkan kreativitasnya. Beberapa aspek penting yang perlu mendapat perhatian dalam pendidikan seni antara lain kesungguhan, kepekaan, daya produksi, kesadaran berkelompok, dan daya cipta. 


\section{Metode Percobaan Sederhana}

Metode atau metdhos adalah bagaimana tata cara penelitian di laksanakan.

Menurut Kamus Besar Bahasa Indonesia (2007:217) Percobaan adalah "Usaha mencoba sesuatu, usaha hendak berbuat atau melakukan sesuatu, dikeadaan dicoba atau (diuji)".

Ilmu pengetahuan alam atau Sains merupakan suatu ilmu teoretis tetapi teori-teori tersebut didasarkan atas pengamatan percobaan-percobaan terhadap gejala-gejala alam. "Betapapun indahnya suatu teori di rumuskan, tidak dapat dipertahankan kalau tidak sesuai dengan hasil-hasil pengamatan/observasi", Abu Ahmadi dan Supatmo (2000:1).

Ilmuan melakukan percobaanpercobaan untuk menguji gagasangagasannya. Metode Percobaan sederhana adalah tata cara percobaan dengan alat dan bahan yang ada disekitar lingkungan kita dan tidak memerlukan biaya yang terlalu mahal dan percobaan-percobaan juga tidak terlalu sulit, maka disebut dengan metode percobaan sederhana.

\section{Langkah - langkah Metode Percobaan Sederhana}

Janice Vancleave (dalam Endang Naskah Alimah) Mengatakan langkahlangkah metode percobaan sederhana yaitu:

a. Merancang tujuan dan tema metode percobaan sederhana

b. Menyediakan alat dan bahan yang digunakan dalam metode percobaan sederhana

c. Merancang langkah-langkah kegiatan metode percobaan sederhana

d. Baca petunjuk dalam melaksanakan metode percobaan sederhana, dengan membaca setiap metode percobaan sebelum memulainya kemudian ikuti petunjuknya dengan benar

e. Amati jika percobaan tidak sama dengan hasil percobaan yang ditunjukan,baca kembali petunjuknya dan mulai dari langkah-langkah pertama.

Metode yang digunakan adalah diskriptif kuantitatif. Menurut Moh. Nazir (2005), "Tujuan penelitian diskriptif adalah untuk mendiskripsikan, menggambarkan, atau ,melukiskan secara lebih detail, faktual, akurat, mengenai fakta-fakta, sifat-sifat serta hubungan antar fenomena yang ada di lapangan".

Diskriptif dilakukan untuk mendiskripsikan tingkat intensitas kunjungan keperpustakaan serta kemampuan mengarang peserta didik yang dijadikan sampel dalam penelitian.

Jenis penelitian kuantitatif dapat diartikan sebagai penelitian yang berlandaskan pada filsafat positivisme, digunakan untuk meneliti pada populasi atau sampel tertentu, teknik pengambilan sampel pada umumnya dilakukan secara random, pengumpulan data menggunakan instrument penelitian, analisis data bersifat kuantitatif atau statistik dengan tujuan untuk menguji hipotesis yang telah ditetapkan. (Sugiyono, 14:2007).

\section{PEMBAHASAN}

Berdasarkan pretes dengan 10 soal pengetahuan awal peserta didik sebelum diberi pengajaran menggunakan metode percobaan sederhana

(Kelas Eksperimen) dan metode ceramah ( Kelas Kontrol ) dapat dinyatakan bahwa tidak ada perbedaan hasil belajar sains ini terlihat $t_{\text {hitung }} 0,897 \geq$ atau $t_{\text {tabel }} 2,021$.

Hasil penelitian postes diakhir pelajaran bahwa $t_{\text {hitug }}=5,206 \geq \mathrm{t}_{\text {tabel }} 2,021$. Pada taraf signifikansi 5\% hal ini berarti hipotesis terbukti bahwa ada perbedaan hasil belajar sains peserta didik yang menggunakan metode percobaan sederhana dengan metode ceramah di 
SDN -3 Kereng Bangkirai Palangka Raya. Hal ini membuktikan bahwa proses pembelajaran yang menggunakan metode percobaan sederhana hasilnya lebih maksimal dibanding dengan proses pembelajaran menggunakan metode ceramah khususnya pada materi pembelajaran benda dan sifatnya : benda padat, benda cair dan benda gas.

Hasil penelitian di atas dapat diketahui kelas eksperimen dengan menggunakan metode percobaan sederhana lebih baik hasil belajar yang dicapai peserta didik daripada kelas kontrol yang hanya menggunakan metode ceramah. Hasil penelitian menunjukan bahwa menggunakan metode percobaan sederhana hasil belajar yang dicapai peserta didik lebih baik dari metode ceramah.

Belajar dengan menggunakan metode percobaan sederhana peserta didik lebih mudah memahami pelajaran sains, menarik perhatian peserta didik, termotivasi dalam belajar sains, berfikir kritis, pengajaran lebih bervariasi, terarah dan tidak monoton sehingga mengurangi kesalahan- kesalahan dalam memahami konsep.

\section{REFERENSI}

Nana Sudjana, ( 2004), Dasar-dasar Proses Belajar Mengajar. Bandung: Sinar Baru Algensindo.

Oemar Hamalik, 2001. Kurikulum dan Pembelajaran, Jakarta : Bumi Aksara.

Pupuh Fathurrohman \& Sobry Sutikno, 2007. Strategi Belajar Mengajar melalui Konsep Umum \& Konsep Islami, Bandung : Refika Aditama.

Purwanto, 2000. Psikologi Pendidikan, Bandung : Remaja Rosdakarya.

Sudjana, N dan Ibrahim., 2001. Penelitian dan Penilaian Pendidikan, Bandung : Sinar Baru Algensindo.

Suparlan,2004. Mencerdaskan Kehidupan Bangsa Dari Konsepsi Sampai Dengan Implementasi, Yogyakarta: Hikayat Publishing.

Sudjana, N dan Rivai, 2002. Media Pembelajaran dan Teknologi, Bandung: Sinar Baru Algesindo. 